\title{
Taxonomic Studies on the Family Fabaceae (Weeds) at Rajshahi University Campus
}

\author{
A. H. M. Mahbubur Rahman, M. Ismot Ara Parvin \\ Plant Taxonomy Laboratory, Department of Botany, University of Rajshahi, Rajshahi-6205, Bangladesh
}

Email address:

ahmmahbubur_rahman@yahoo.com (A. H. M. M. Rahman)

\section{To cite this article:}

A. H. M. Mahbubur Rahman, M. Ismot Ara Parvin. Taxonomic Studies on the Family Fabaceae (Weeds) at Rajshahi University Campus. Plant. Vol. 3, No. 3, 2015, pp. 20-25. doi: 10.11648/j.plant.20150303.11

\begin{abstract}
Taxonomic investigation on the family Fabaceae (weeds) growing throughout the Rajshahi University campus was carried out. A total of 10 species under 8 genera of the family Fabaceae were collected and recorded for their use in various ailments. A complete taxonomic account of each species has been given along with their scientific name, local name, habit, habitat, flower color, flowering season, population, uses and specimens examined. Out of the total number of species Alysicarpus vaginalis DC., Clitoria ternatea L., Desmodium triflorum (L.) DC., Desmodium gangeticum (L.) DC., Vicia sativa L., Vicia hirsuta L., Sesbania bispinosa Jacq. were frequent and Melilotus indica L., Abrus precatorius L. and Uraria picta Desv. were rare species in the study area.
\end{abstract}

Keywords: Weed Species, Taxonomic Studies, Fabaceae, Rajshahi, Bangladesh

\section{Introduction}

Rajshahi University or University of Rajshahi is a public university located in Rajshahi, a city in north-western Bangladesh. Rajshahi University was established in 1953, the second university to be established in what was then East Pakistan. The university's forty-nine departments are organized into nine faculties. Rajshahi University is located in a 753 acres $\left(3 \mathrm{~km}^{2}\right)$ campus in Motihar, 3 kilometers $(2$ miles) from the Rajshahi city centre. With 25,000 students and close to 1000 academic staff, it is one of the largest universities in Bangladesh [22].

The study area conducted at Rajshahi University campus, Rajshahi district. The type of land of study area such as follow land, cultivated land, grazing and non-grazing land. For this reason various kinds of plant is present this study area; such as shrubs or trees, very rarely herbs. The soil all around of Rajshahi University is alluvium. The texture of the soil is sandy loam. The soil pH of Rajshahi University is 7.5. The climate of Rajshahi University is not characterized by great extremes of heat, cold and rainfall. The hot season commences early in the march with the cessation of the northerly wind. The winter season (November-December) which is cool and rainless; summer season (June-October) which is warm and humid and during which $90 \%$ or more of the total rain occurs.
In terms of temperature variation it appears that average annual temperature is about $25.36^{\circ} \mathrm{C}$. The maximum monthly temperature can be search up to $40.1^{\circ} \mathrm{C}$ during May and minimum monthly temperature $9^{0} \mathrm{C}$ during January. Data on temperature included in this table have been from monthly statistical bulletin of Rajshahi, Bangladesh. Relative humidity percentage ranged from $61.96 \%$ with an annual average of $82.87 \%$. Data on relative humidity included in this table have been recorded from monthly statistical bulletin of Rajshahi, Bangladesh. The maximum amount of monthly rainfall being $674 \mathrm{~mm}$. in July and minimum amount of monthly rainfall being $03 \mathrm{~mm}$. in January [2].

The Fabaceae or Leguminosae, commonly known as the legume, pea, or bean family, are a large and economically important family of flowering plants. The group is the thirdlargest land plant family, behind only the Orchidaceae and Asteraceae, with 730 genera and over 19,400 species. The largest genera are Astragalus (over 2,400 species), Acacia (over 950 species), Indigofera (around 700 species), Crotalaria (around 700 species), and Mimosa (around 500 species). Plants of this family are found throughout the world, growing in many different environments and climates. A number are important agricultural and food plants, including Glycine max (soybean), Phaseolus (beans), Pisum sativum (pea), Cicer arietinum (chickpeas), Medicago sativa (alfalfa), Arachis hypogaea (peanut), Ceratonia siliqua (carob), and Glycyrrhiza glabra (licorice). A number of species are also 
weedy pests in different parts of the world, including: Cytisus scoparius (broom), Ulex europaeus (gorse), Pueraria lobata (kudzu), and a number of Lupinus species [21].

\section{Materials and Methods}

Taxonomic investigation on the family Fabaceae (weeds) growing throughout the Rajshahi University campus was carried out during the period of January 2011 to March 2012. A total of 10 species under 8 genera of the family Fabaceae were collected and identified. A survey on the determination of the location of different species was made and a list was prepared to be acquainted with the Fabaceae available in the selected area. All the species were noted and time to time the areas were visited to see when they flowered. For the morphological study, different types of species were examined again and again in order to see if there was any variation or not. They were collected at flowering stages and herbarium specimens were prepared as vouchers. In this practice standard method was followed. In this regard different types of plant species were collected from different habitats. All the collected plant specimens were kept in the Herbarium, Department of Botany, University of Rajshahi, Bangladesh.

The collected specimens were identified studying related taxonomic books and booklets from the library of Rajshahi University. The major collected materials were identified and described up to species with the help of [6], [12], [13], [14], [15], [16], [17], [18], [19], [20], [4] and [8]. In some cases [9], [5] and [3] were consulted. For the current name and up to date nomenclature [7], [10] and [11] were consulted.

\section{Results and Discussion}

Taxonomic investigation of the family Fabaceae (weeds) growing throughout the Rajshahi University campus was carried out during the period of January 2011 to March 2012. A total of 10 species under 8 genera of the family Fabaceae were collected and identified. A complete taxonomic account of each species is given with current nomenclature, local name, occurrence, habit, flowering season, population and uses. Most of the species are distributed all over the study area. Out of the total number of species Alysicarpus vaginalis DC., Clitoria ternatea L., Desmodium triflorum (L.) DC., Desmodium gangeticum (L.) DC., Vicia sativa L., Vicia hirsuta L., Sesbania bispinosa Jacq. were frequent and Melilotus indica L., Abrus precatorius L. and Uraria picta Desv. were rare species in the study area.

The family Fabaceae consists of about 440 genera and 12000 species, wide spread in temperate and cold as well as tropical regions. In Bangladesh, this family is represented by 69 genera and 254 species [1]. The Fabaceae are a very large family which includes those plants which are sometimes referred to as the pulses or, in common parlance, the peas and beans. These plants are biologically remarkable in that they possess the power of utilizing atmospheric nitrogen, through the agency of the bacteria which occur in nodules in their roots. In consequence they are of first rate importance in agriculture. Not only are the seeds rich in food reserves and therefore valuable for food, but at the same time the aerial parts are useful as cattle fodder. After these have been cut and gathered, the roots left behind liberate nitrates as they decay and so improve the soil [9].

By examining the plant materials collected from the study area using the identification methods and medicinal information was accumulated and described below.

\subsection{Abrus Precatorius $L$.}

Taxonomic description: A perennial, dextrose climber with slender and tough branches, up to $4.5 \mathrm{~m}$ long and $2 \mathrm{~cm}$ in diameter. Leaves 5-10 cm long, paripinnate, leaflets 10-20 pairs, opposite, $7.5 \times 3.5 \mathrm{~mm}$, slightly increasing in size from the base, linear or linear oblong, thinly membranous, entire, rounded at both ends, glabrous above, thinly ad pressed silky beneath, stipules linear, deciduous, petioles up to $1.2 \mathrm{~cm}$ long Flowers in raceme, crowded, $1.0-1.3 \mathrm{~cm}$ long, arranged on the rachis one side. Calyx $2 \mathrm{~mm}$ long, thinly silky. Corolla pink or white (Fig. I).

Local name: Kunch

Habit: Perennial climber

Habitat: Village thickets and forests.

Flower color: Pink or White.

Flowering season: July-September

Population: Rare

Uses: Seeds contain to lectins, abrin-a and abrin-b, and ribosome inactivating proteins. Seeds are abortifacient, emetic, purgative, antimicrobial, anticancerous, tonic and aphrodisiac. Roots are emetic and alexertic. Paste of seeds is used in paralysis and skin diseases. Leaves are used in bilioousness, leucoderma, itching and other skin diseases. Roots are used as a substitute for liquorice as emitic and emmenagogue and in obstinate coughs.

Specimens examined: MIAP 09, 31-02-2012. Botanical garden of R.U. campus.

\subsection{Alysicarpus Vaginalis DC.}

Taxonomic description: A diffuse. annual herb. Stem robust, ascending, c $1 \mathrm{~m}$ long, glabrescent or with little adpressed hairs. Leaflet glabrous, $1.5-2.5 \mathrm{~cm}$ long, about twice as long as broad, usually oblong, rarely lanceolate, obtuse at the apex, cordate at the base. Racemes elongated, 612 flowerd, 5-7 cm long, pedicels shorter than the calyx. Calyx glabrous, teeth linear, setaceous, exceeding the tube, slightly connate below, lobes glumaceous, subequal, only the upper 2 connate near the apex. Petals exserted, standard obovate or orbicular, narrowed into a claw, wings obliquely oblong, adnate to the keels, keels slightly incurved, obtuse. Stamens 10, vexillary filaments free, the other connate (Fig. A).

Local name: Pan-nata

Habit: Herb

Habitat: Wet grassland

Flower color: Purple

Flowering season: July- August 
Population: Frequent

Uses: Used as green manure, cover crop and fodder.

Specimens examined: MIAP 01, 09-07-2011. East, West North and South of R.U. campus.

\subsection{Clitoria Ternata Linn.}

Taxonomic description: A perinnial twining herb. Stem terete, more or less pubescent. Leaves imparipinnate. Leaflets 5-7, subcoriacious, elliptic-oblong, obtuse, glabrous or with few short appressed hairs, apex acute, base obtute or acute, stipules long, linear, acute, stipels filifrom. Flowers axillary, solitary, pedicels long, bracts 4-5 mm long, linear, bracteoles $7 \mathrm{~mm}$ long, roundish, obtuse. Calyx 1.2-1.6 cm long, teeth lanceolate, shorter than the tube. Corolla long, the standard petal bright blue or white. Stamens diadelphous, 9+1, vexillary stamens free. Ovary hairy, styles simple (Fig. H).

Local name: Aparajita

Habit: Herb

Habitat: Fallow lands.

Flower color: Blue

Flowering season: June-March

Population: Frequent

Uses: The root is bitter, used as demulcent, aperients, laxative and diuretic. The seeds are purgative and aperients. Roasted powdered seeds are used in the treatment of ascities, enlargement of abdominal viscera, weakness of sight, sore throat, tumors, dropsy and skin diseases. The juice of leaves mixed with common salt is applied for relief of pain of ear. The root, stem and flowers are recommended in snakebite and scorpion sting.

Specimens examined: MIAP 08, 09-08-2011. East, West, North and South of R.U. campus.

\subsection{Desmodium Triflorum (L.) DC.}

Taxonomic description: A small herb. Stem caespitose, very slender, trailing, $15-25 \mathrm{~cm}$ tall, copiously branched, clothed with the fine spreading hairs. Leaflets obovate, 1-4 $\mathrm{cm}$ long, truncate or emarginated, with a few adpressed hairs below, stipules lanceolate, persistent, petioles $2-5 \mathrm{~cm}$ long. Flowers pedicellate, pedicels 1-2 cm long, Calyx pubescent, 1-2 cm long, teeth very long, setaceous (Fig. B).

Local name: Salpani, Chalani.

Habit: Undershrub

Habitat: Shady place as undergrowth

Flower color: Greenish white.

Flowering season: April-November

Population: Frequent

Uses: Roots possess astringent, anthelmintic, aphrodisiac and tonic properties, and are useful in typhoid, fever, piles, asthma, bronchitis, cough, biliousness, dysentery and diarrhea.

Specimens examined: MIAP 02, 11.10.2011. East, West, North and South of R.U campus.

\subsection{Desmodium Gangeticum (L.) DC.}

Taxonomic description: An undershrub, 60-120 cm tall.
Stem woody, slightly angular, clothed with short grey, pubescent upwards. Leaves unifoliate, leaflets oblong, usually 3-6, rounded at the base, narrowed gradually to an acute point, thinly clothed beneath with grey hairs, petioles 1.5-2.5 cm long, Inflorecence a raceme, copious, ascending, lateral and terminal, sublax, $15-20 \mathrm{~cm}$ long, simple or with a few short ascending brunches in the lower part, pedicels 4-8 $\mathrm{mm}$ long, ascending, bracts minute, setaceous. Calyx $3 \mathrm{~mm}$ long, pubescent, teeth lanceolate. Corolla 3-6 mm long (Fig. C).

Local name: Salpani, Chalani.

Habit: Undershrub

Habitat: Shady place as undergrowth

Flower color: Greenish white.

Flowering season: April-November

Population: Frequent

Uses: Roots possess astringent, anthelmintic, aphrodisiac and tonic properties, and are useful in typhoid, fever, piles, asthma, bronchitis, cough, biliousness, dysentery and diarrhea.

Specimens examined : MIAP 03, 11.10.2011. East, West, North and South of R.U campus.

\subsection{Melilotus Indica (L.) All.}

Taxonomic description: An erect, annual herb, 15-60 cm height. Stem and branches pale, slightly striate, pubescent. Leaves trifoliolate, leaflets $12-25 \times 8-10 \mathrm{~mm}$, toothed, oblong, oblanceolate or obovate-cuneate, rounded, truncate or retuse at the apex, glabrous or a few hairs on the both surface, petiols of lateral, leaflets very short, those of terminal leaflets long, up to $3.5 \mathrm{~cm}$ long. Flowers small, in spicate raceme, Pedicels $1 \mathrm{~mm}$ long, teeth triangular. Corolla twice as long as the calyx, yellow (Fig. D).

Local name: Bon methi

Habit: Herb

Habitat: Waste and fallow lands.

Flower color: Yellow

Flowering season: February-August

Population: Rare

Uses: Seeds are used for the treatment of infantile diarrhoea. The plant is used externally as fomentation, poultice or plaster for swellings.

Specimens examined: MIAP 04, 07-05-2011. East of R.U. campus.

\subsection{Sesbania Bispinosa Jacq.}

Taxonomic description: A sparingly branched, annual or biennial, 1-3 m tall. Stem semi woody, sparsely pubescent when young, branches and leaf rachis often prickly. Leaves abruptly pinnate, stipules membranous, acuminate, caducous, leaflets 40-110, linear - oblong, 1-2 cm long, obtuse, strongly mucronate, glabrous, base acute, petioles very short. Flowers in lax axillary, 3-12 flowered, drooping racems. calyx $5 \mathrm{~mm}$ long, membranous, glabrous, teeth deltoid, much shorter than the tube. Corolla yellow, violet, flecked, standard glabrous (Fig. J). 


\section{Local name: Dhaincha}

Habit: Herb

Habitat: village thickets and marshy lands.

Flower color: Yellow

Flowering season: May- October

Population: Frequent

Uses: The green leaves are good fooder. The stem has a strong rush fiber, used as fuel and making charcoal. The plant is good atmospheric nitrogen fixer.

Specimens examined: MIAP 10, 22-01-2012 East, west, North and South of R.U campus.

\subsection{Uraria Picta Desv.}

Taxonomic description: A suffruticose, sparingly branched, perennial herb or undershrub. Stem stout, finely downy with hooked hairs. Leaves imparipinnate, leaflets on the upper parts of the stem 5-7, rigidly subcoriaceous, linear-oblong or ovate-lanceolate, acute, glabrous above, finely articulately vained, minutely pubescent beneath, base rounded, leaflet on the lower part of the stem 1-3 foliolate, ovate or oblong, petioles 3.5-6.0 cm long, striate, downy, stipules $4-5 \mathrm{~mm}$ long, triangular, long acuminate, striate, stipels subulate. Flowers in close facicle along the rachis or spicate-cylindric racems, rachis and pedicles downy with hooked hairs, pedicles curved upward after flowering, bracts large, scarious, striate, strongly ciliate, the upper lanceolate-acuminate, the lower ovate-acuminate, completely concealing in buds, soon deciduous. Calyx 4-5 mm long, teeth plumose, subulate, much longer than the tube. Corolla purple, pink or bluish, 8-9 mm long, slightly exserted (Fig. E).

Local name: Shankar jata

Habit: Perennial herb or undershrub

Habitat: Grass lands or forests.

Flower color: purple

Flowering season: June-December.

Population: Rare

Uses: The plant is supposed to be a good antidote in worm biting. Root is aphrodisiac, decoction is used in cough, chill and fever.

Specimens examined : MIAP 05, 15-07-2011. North of R.U. campus.

\subsection{Vicia Sativa $L$.}

Taxonomic description: An annual, procumbent herb. Stem slender, glabrous or obscurely downy. Leaves pinnately compound, rachis ending in a tendril, stipules 3-8 mm long, semisagittate, stipels absent, leaflets 4-18, 1-4 cm long, linear to lanceolate or obovate. Flowers 1-2, subsessile or shortly pedicellate. Calyx $2 \mathrm{~mm}$ long, teeth lanceolate, subulate, lobes subequal or the upper 2 shorter than the lateral. Petals pale pink, crismon, purplish-violet, twice the calyx, standard obovate, emerginate, narrowed into a wide claw, wings oblong, oblique, adnate at the middle to the shorter keels. Stamens10, vexillary one free or slightly connate with the rest, anthers uniform. Ovary subsessile or stipitate, usually many-ovuled, styles inflexed, filifrom or flattened, usually pubescent with dorsal tuft or subapical ring of hairs, stigmas terminal, capitat (Fig. F).

Local name: Ankari, Hatka

Habit: Herb

Habitat: High lands where it is cultivated.

Flower color: Purplish-violet.

Flowering season: July-November.

Population: Frequent

Uses: It can fix atmospheric nitrogen. It is also used as fodder.

Specimens examined: MIAP 06, 01-11-2011. East, West, North and South of R.U campus.

\subsection{Vicia Hirsuta L.}

Taxonomic description: An annual weedy, straggling, climbing herb, 30-60 cm tall. Stem sparsely pubescent with fine soft hairs. Leaves even pinnate, stipulate, stipules $4-5 \times$ 0.7-1.0 mm, oblong or lanceolate, semisagittate, sometimes 3 lower lobes divided into 3 filifrom segments, persistent, rachis ending in a branched tendril, leaflets 6-10 pairs, 4-15 $\times$ 0.5-2.5 mm, linear to narrowly oblong, obtuse, truncate or emerginate at the apex, mucronate, cuneate at the base, glabrous. Inflorescence an axillary peduncles raceme, peduncles up to $4 \mathrm{~cm}$ long, consisting of 2-7 flowers. Flowers white, 4-5 mm long, pedicellate, pedicels 0.5-2.0 $\mathrm{mm}$ long. Calyx campanulate, 2.5-3.0 $\mathrm{mm}$ long, 5-teethed, linearoblong, pubescent outside. Corolla exserted, petals 5, all the petals more or less equal in length, clawed, standard petal 3-5 mm long, ovate-oblong, enclosing the keel and wing petals. Stamens 10, monadelphous, filaments united to form a staminal sheath, anthers uniform. Ovary pubescent, styles pubescent at the apex (Fig. G).

Local name: Masurechana

Habit: Annual herb

Habitat: Agricultural lands, open grasslands, roadsides, nurseries and gardens.

Flower color: White.

Flowering season: December-March

Population: Frequent

Uses: Weedy herb, usually used as forage for cattle mixed with other grasses. Sometimes used as food, drink and medicine.

Specimens examined: MIAP 07, 03-01-2012. East, West, North and South of R.U. campus.

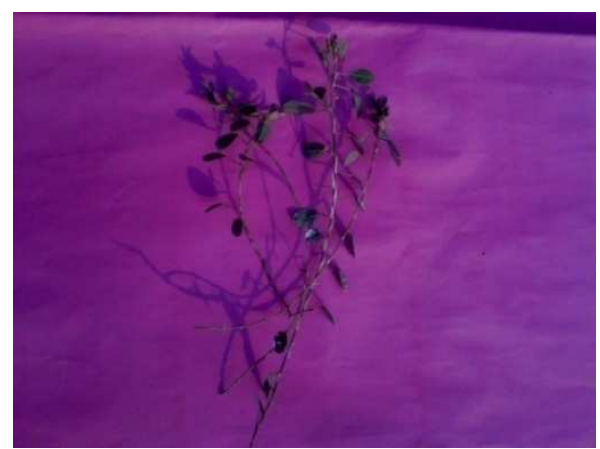




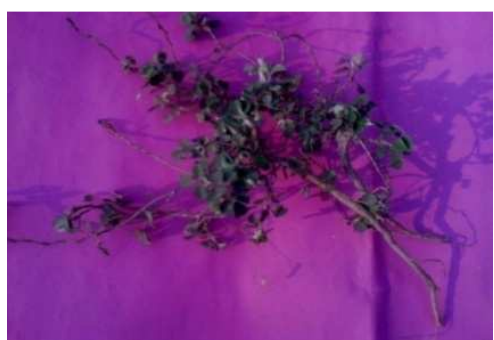

B

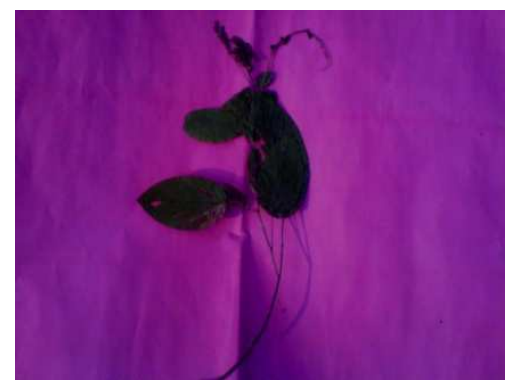

$\mathrm{C}$
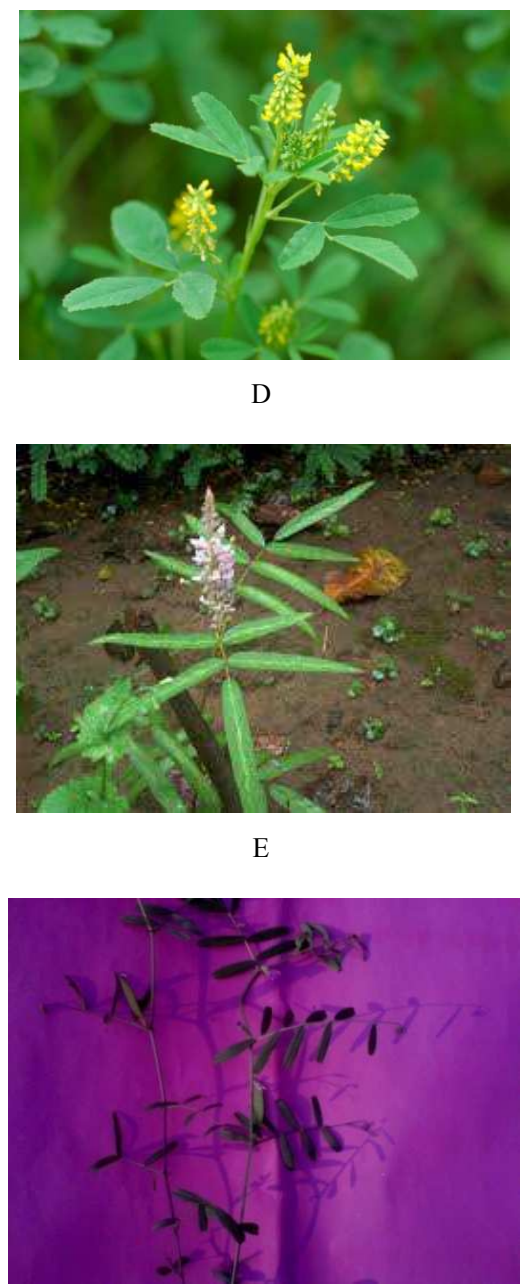

$\mathrm{F}$

Fig. A. Alysicarpus vaginalis DC., B. Desmodium triflorum (L.) DC., $\boldsymbol{C}$. Desmodium gangeticum (L.) DC., D. Melilotus indica (L.) All., E. Uraria picta Desv., $\boldsymbol{F}$. Vicia sativa $L$.

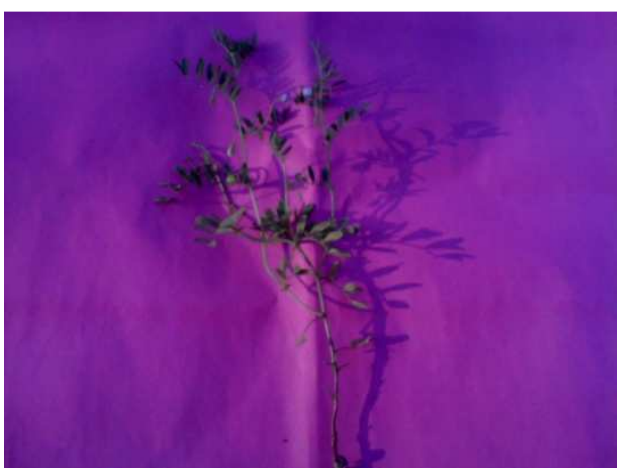

G

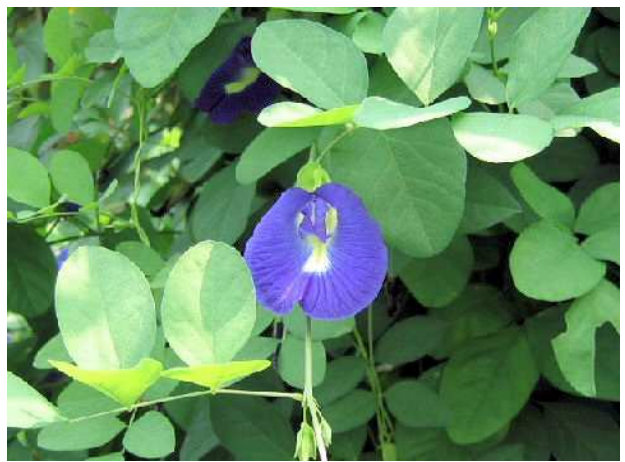

$\mathrm{H}$
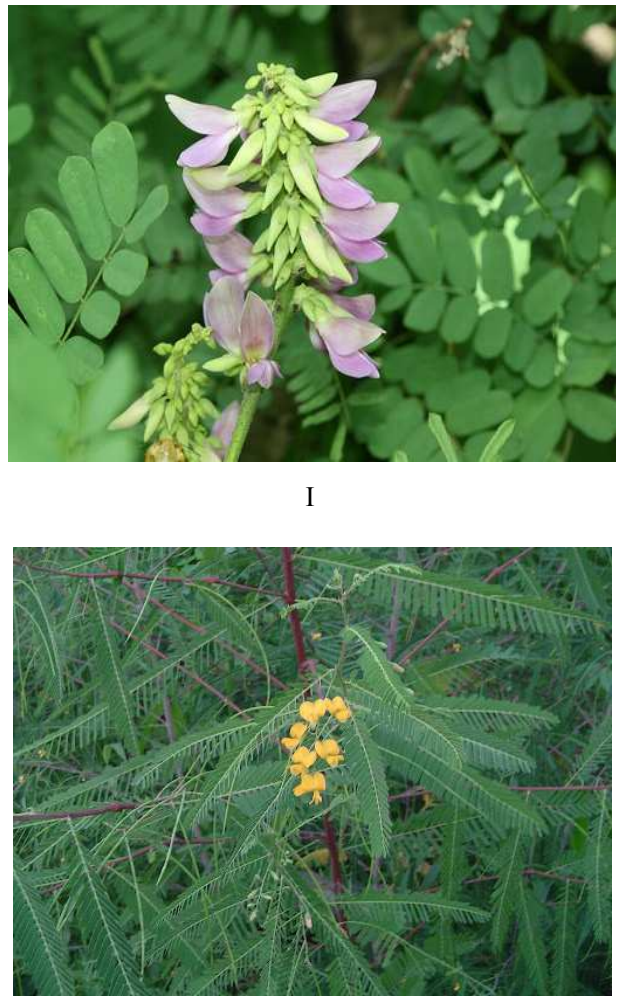

Fig. G. Vicia hirsuta L., H. Clitoria ternata L., I. Abrus precatorius L., J. Sesbania bispinosa Jacq.

\section{Conclusion}

Taxonomic investigation on the family Fabaceae (weeds) 
growing throughout the Rajshahi University campus was carried out. A total of 10 species under 8 genera of the family Fabaceae were collected and recorded for their use in various ailments. Out of the total number of species Alysicarpus vaginalis DC., Clitoria ternatea L., Desmodium triflorum (L.) DC., Desmodium gangeticum (L.) DC., Vicia sativa L., Vicia hirsuta L., Sesbania bispinosa Jacq. were frequent and Melilotus indica L., Abrus precatorius L. and Uraria picta Desv. were rare species in the study area.

\section{Acknowledgements}

The authors are grateful to the local people of Rajshahi University campus for their cooperation and help during the research work.

\section{References}

[1] Ahmed Z U, Begum Z N T, Hassan M A, Khondker M, Kabir S M H, Ahmad M, Ahmed A T A, Rahman A K A and Haque E U(Eds). Encyclopedia of Flora and Fauna of Bangladesh. Angiosperms; Dicotyledons. Asiatic Society of Bangladesh, Dhaka., Vol 8, 2009.

[2] BBS (Bangladesh Bureau of Statistics). Statistical Year Book of Bangladesh, $23^{\text {rd }}$ edition, Bangladesh Bureau of Statistics, Planning Division, Ministry of Planning Government of Peoples Republic of Bangladesh, Dhaka., 2009.

[3] Bhattacharyya B and Johri B M. Flowering Plants Taxonomy and Phylogeny. Prokas Publishers, Calcutta, India., 1998.

[4] Cronquist A. The Evolution and Classification of Flowering Plants. Houghton Miftlin, Boston. U.S.A., 1968.

[5] Heywood V H. Flowering Plants of the World. Oxford University Press, New York, U.S.A., 1979.

[6] Hooker J D. Flora of British India. Voi.1-7. L. Reeve and Co. Ltd. London., Vol 1-7, 1961.

[7] Huq A M. Plant Names of Bangladesh. Bangladesh National Herbarium, BARC, Dhaka, Bangladesh., 1986; pp.1-289.

[8] Kirtikar K R and Basu B D. Indian Medicinal Plants. Lalit Mohan Basu, Allahabad, Jayyed Press, New Delhi, India., Vol $1-4,1987$.

[9] Lawrence G H M. Taxonomy of Vascular Plants. Oxford and IBM Publishing Co., Rakes Press, New Delhi, India., 1973.
[10] Pasha M K and Zaman M B. Name Changes in Plants of Bangladesh. Chittagong University Studies, Part-II, Science Vol. 12(1), 1988; pp.107-112.

[11] Pasha M K and Uddin S B. Dictionary of Plant Names of Bangladesh. Janokalyan Prokashani, Chittagong-4000, Bangladesh., 2013; pp.1-434.

[12] Prain D. Bengal Plants. Botanical Survey of India. Calcutta, India. Vol 1-2, 1963.

[13] Rahman AHMM. 2013. A Checklist of Common Angiosperm Weeds of Rajshahi District, Bangladesh. International Journal of Agricultural and Soil Science. 1(1): 1-6.

[14] Rahman AHMM. 2013. Angiospermic flora of Rajshahi district, Bangladesh. American Journal of Life Sciences. USA. 1(3): 105-112.

[15] Rahman AHMM. 2013. Graveyards angiosperm diversity of Rajshahi city, Bangladesh with emphasis on medicinal plants. American Journal of Life Sciences. USA. 1 (3): 98-104.

[16] Rahman AHMM, Ferdous Z and Islam AKMR. 2014. A Preliminary Assessment of Angiosperm Flora of Bangladesh Police Academy. Research in Plant Sciences. USA. 2(1): 9-15.

[17] Rahman AHMM and Rahman MM. 2014. An Enumeration of Angiosperm weeds in the Paddy field of Rajshahi, Bangladesh with emphasis on medicinal Plants. Journal of Applied Science And Research. USA. 2(2): 36-42.

[18] Rahman AHMM, Hossain MM and Islam AKMR.. 2014. Taxonomy and Medicinal Uses of Angiosperm weeds in the wheat field of Rajshahi, Bangladesh. Frontiers of Biological and Life Sciences. USA. 2(1): 8-11.

[19] Rahman AHMM and Debnath A. 2014. Angiosperm Diversity of Pandit Para Village under Palash Upazila of Narsingdi District, Bangladesh. Frontiers of Biological \& Life Sciences. USA. 2(4): 98-105.

[20] Rahman AHMM and Keya MA. 2014. Assessment of Angiosperm Flora at the Village Sabgram under Sadar Upazila of Bogra District, Bangladesh. International Journal of Advanced Research. India. 2(11): 443-458.

[21] Stevens P F. Angiosperm Phylogeny Website Version 9, 2008.

[22] TFR (Task Force Review). Education Bangladesh. UN Online Network in Public Administration and Finance. 2003. P. 11. Retrieved 2006-03-14. 